\title{
The Influence of Customer Perception on the Relationship Between Green Marketing Practices and Customer Satisfaction in the Soft Drink Industry in Nairobi Kenya
}

\author{
Dr. Rachael Wairimu Macharia
}

\begin{abstract}
The objective of this study was to establish the influence of customer perception on the relationship between green marketing practices and Customer Satisfaction in the soft drink industry in Kenya. This study was anchored on consumer behavior theory and was guided by positivistic philosophy. The study adopted a descriptive cross-sectional research design to determine how green marketing practices affect customer satisfaction in soft drink companies in Nairobi County, Kenya and how the relationship is influenced by customer perception. The study targeted a sample of 180 trade customers but, the researcher managed to successfully collect data from 130 of the trade customers. The study adopted Cronbach's Alpha. Descriptive statistics (mean scores and measures of dispersion) and inferential statistics (correlation, analysis of variance and regression analysis) was conducted to determine the expected relationships between green marketing practices and customer satisfaction. $\mathrm{R}^{2}$ increased from .121 to .223 when customer perceptions were included (.223$.121=.102)$. The results imply that customer perception explain an additional $10.2 \%$ of the variation in customer satisfaction. The results indicate that the effect of green marketing practices on customer satisfaction in the final step of the analysis (path c) is significant at 0.05 significance level. The regression coefficient reduced from $\beta=.389$ in path "a" to $\beta=.349$ in path c' and was statistically significant at 0.05 level of significance. Based on the overall study results obtained from the tests of the study hypotheses, it is concluded that customer perception had a statistically insignificant mediating effect on the relationship between green marketing practices and customer satisfaction
\end{abstract}

Keywords: Customer Perception, Green Marketing Practices, Customer Satisfaction, Soft Drink Industry, Nairobi Kenya

DOI: $10.7176 / \mathrm{EJBM} / 11-3-17$

\section{Introduction}

In various theoretical paradigms used in business research the role of customer perception in the relationship between the green marketing practices and satisfaction is implied. The corporate environmentalism theory (Menon \& Menon, 1999; Friedman,1970) and Consumer behavior theory and its constituent theories (Bagozi, 1992; Oliver, 1980; Schiffman \& Kanuk, 2007) anchor the relationship between green marketing practices, customer satisfaction and customer perception.

With consumers becoming more health-conscious, green marketing remains a key growth driver. The rising health awareness has bolstered demand for non carbonates (juice and water) with manufacturers in all major soft drinks categories responding by diversifying their portfolios. Although soft drink companies could realize the benefits of energy efficiency to their business which motivates them to implement green technologies, there is a lack of knowledge about the factors affecting the green customer satisfaction in the soft drink industry in Kenya, which does not encourage the companies to benefit from green practices. The study suggested that soft drink companies can benefit more by adding value to their brand by enhancing their brand image and spreading awareness among customers about the environmental responsibility.

Research has shown that consumers are very much concerned and sensitive regarding some factors which include; green product consumer loyalty, environmental awareness, luxury and quality price. Therefore, investigating green strategies to enhance product's performance and strengthening green product's customer loyalty is imperative (Peattie, 1995; Kinoti, 2012). Most studies have focused on the quality of the product, brand image, Performance, corporate image and consumer loyalty. Only a few of them have investigated about green customer perception aspects. The corporate environmentalism theory (Menon \& Menon, 1999) and consumer behavior theories (Schiffman \& Kanuk, 2007; Bagozi, 1992; Oliver, 1993) anchor the connection among green marketing activities, customer perception and satisfaction. Hence, the effect of customer perception on the relationship between customer satisfaction and green practices was tested in this study. It is against this background that this study filled the knowledge gap on the relationship between green marketing practices and customer satisfaction and how it is mediated by customer perception.

The practice of marketing has become more people-oriented. Marketing theory emphasizes decision making of marketing managers, interpreting it in terms of decision models. These explanations range from the decisions made in consideration of four variables: products, place, promotion, and price the four "p's" to comparativism, or the relating of marketing practice to ecological factors in the cultural environment (Bartels, 1968). 


\subsection{Green Marketing}

Green marketing practices refers to the activities concerned with promotion of environmentally safe products. Different scholars use various terminologies to describe green marketing. These include: green marketing, environmental marketing and ecological marketing (Polonsky, 1995). The American Marketing Association (AMA) refers green or ecological marketing as the study of the positive and negative aspects of marketing activities on pollution, energy depletion and non-energy resource depletion (Kinnear, 1973). AMA describes green marketing as the marketing of products that are presumed to be environmentally safe. It incorporates several activities such as product modification, changes to production processes, packaging, advertising strategies and also increases awareness on compliance marketing amongst industries.

Environmental pollution of industrial manufacturing activities in the world, leads to consumers increased environmental awareness (Chen, 2011; Ottman, 2011). As a result, companies are more willing to take environment protection as their social responsibility and would like to take advantage of green opportunities (Dwyer, 2009; Molina-Azori'n et al., 2009). Firms have recognized the positive gains that can be achieved through environmentally friendly marketing strategies and the potential drawbacks associated with nonenvironmentally friendly strategies (Luo \& Bhattacharya, 2006).

In the environmental context, companies need to pay more attention to green marketing to products, Processes, distribution and communication (Kalafatis \& Pollard, 1999). However, not all companies have enough capability to implement green marketing strategies. Buil-Carrasco et al (2006) identified company size as one of the most important determinants of the firm's environmental strategy or corporate involvement. Large firms tend to present a more positive attitude toward the environment because their pollution rates are higher. In addition, firms operating in the most polluting sectors also consider corporate environmentalism factor due to the higher social and regulatory demands. The ownership structure of the firm also influences the relationship between environmental responsibility and market worth. Zheka (2005) found that firm ownership structure has an impact on corporate governance, corporate power and investors' perception towards environmental responsibility. Organization's culture and ownership structure influences employees' behaviour and attitude. The products and services produced by the organization's employees to be consumed by the organization's customers are the embodiment of the attitudes and behaviours of the employees who produce them (Klein et al, 1995). If companies would like to undertake green marketing successfully, they should integrate the concepts of green marketing into all aspects of conventional marketing activities.

\subsection{Customer Perception}

Perception is the process by which an individual selects, organizes and interprets stimuli into meaningful and coherent picture of the world (Schiffman \& Kanuk, 2009). It is the process by which people translate sensory impressions into a coherent and unified view of the world around them. Simply stated, it is how we see the world around us. Customer perception is the selection, organization and interpretation of marketing and environmental stimuli into a coherent picture. Marketers attempt to influence customer perception by creating an image of a brand that connotes value and reliability (Assad, 2004). Kibera and Waruingi (2009) summarized perception as the process which attributes meaning to incoming stimuli through the human senses. According to the above authors, our perception of an object or event is the result of the interaction of two types of factors: stimuli factors which are characteristics of the physical object such as size, colour, weight or shape and personal factors which are characteristics of the individual.

Wright (2006) describes a brand as a collection of perceptions in the mind of the individual consumer. To some it means nothing but to the target market (green customers) it means value, quality satisfaction and ultimately an overall meaningful feeling of well being (Oliver, 2006). Customer perception directly affects consumption due to the fact that customers view brands benefits differently, hence the significant relationship between customer perception and customer satisfaction. Perceived quality is also described as brand association that is elevated to the status of a brand asset for reasons that among all brands associations. Only perceived quality has been shown to drive financial performance (Aaker, 1996). Perceived quality is often a major strategic thrust of a business and green marketing to green customers can be used to create a perception of quality. Therefore, green brands are also likely to develop the 'well being' and quality perception of the environmentally sound products. Perception of quality affects the value of brand positively or negatively and thereby affects the purchase behaviour of consumers (Aaker, 1996; Kabare, 2013).

\subsection{Customer Satisfaction}

According to Oliver (1997) satisfaction refers to a consumer's judgment that a product or service feature, or the product or service itself, was providing a pleasurable level of consumption-related fulfillment, including levels of under or over-fulfillment. Customer satisfaction can be seen as a fulfillment of consumer's consumption goals as experienced and described by consumers (Oliver, 2006). Therefore, customer satisfaction is important for companies and other organizations in their efforts to improve product and service offerings and maintain 
customer loyalty in the face of growing intensity of green competition. Satisfaction also refers to a customer's overall evaluation of how pleasurable their interaction with an organization is including the buying and use experience, relative to his or her expectations.

The relevant marketing literature suggests that there is a relationship between customer satisfaction and loyalty. Satisfaction leads to attitudinal loyalty. It could be seen as the intention to purchase (Menon, 1999). Satisfaction is an outcome that occurs without comparing expectations and could also be an evaluative response to perceived outcome of a particular consumption experience. It is an overall judgment on satisfaction based on the assumption that satisfaction is the outcome of service quality. Therefore, green satisfaction (GS) is defined in this study as a pleasurable level of consumption-related fulfillment in order to satisfy specific green needs and environmental responsibilities (Chen, 2009). Customer satisfaction is closely linked to future purchase behaviour and willingness to recommend and is a strong predictor of loyalty and customer retention (Kabare, 2013). A satisfied customer will not complain but refer others to their service providers. This is determined by customer satisfaction assessment that is used to develop a strong value proposition, one that is persuasive, distinctive, measurable, defendable and sustainable ( Krivobokova, 2009).

\subsection{Soft drink Industry}

The soft drink companies in Kenya fall within a vibrant food and beverage sector of the wider economy that has experienced immense product proliferation. The industry has many players which include manufacturers, wholesalers, retailers, packers and regulators but this study will focus on the manufacturers and their direct trade customers. All the players are expected to practice green marketing as a corporate social responsibility and at the same time satisfy the green customer to their competitive edge. There is fierce competition that forces companies to diversify their product range in an effort to better satisfy the customers. The entry rate into the industry has been increasing resulting to an erosion of profits for the manufacturers. It has been shown that large and old companies remain in the industry as the young and small company exit because of that competition. Organizations thus, have been forced to implement changes to align themselves with the changes in the environment as well as to realize their set goals.

Although there are several green marketing practices, consumer responses to these practices are varied. Empirical studies to date provide minimal evidence of customer perceptions' influence on satisfaction. Few studies have assessed these green marketing practices alongside enabler variables yet satisfaction can be associated with perception (Prakash, 2002). The current study brought together green marketing practices, enabler variables (organizational demographics) and customer perception in the assessment of customer satisfaction.

\subsection{Literature Review}

Consumer behaviour theory contends that a consumer internal influences such as motivation, perception and attitudes interplay with external influences from reference groups, culture, social class and marketing activities that shape consumer needs and desires leading to a consumption decision process (Schiffman \& Kanuk, 2007). Consumer behaviour theories that seek to explain how consumer perceptions and attitudes are formed include the theory of reasoned action (Fishbein \& Ajzein, 1975), the theory of planned behaviour (Chiou, 1998), the theory of trying (Bagozi, 1992), the tri-component attitude model (Oliver, 1993) and expectancy disconfirmation model (Oliver, 1980). The general argument of these theories is that satisfaction is a result of the difference between expected and perceived performance. Consumers compare performance expectations with the actual buying and the use experience. Therefore, firms aim to maximize customer satisfaction by managing expectations through appropriate marketing mix variables hence green marketing practices.

Green marketing practices reflect positively on company's intangible brand equity. Building a strong brand has always been a main objective, since it provides a lot of benefits such as larger margins, greater opportunities for extension and maintaining strong position against competitors (Delgado \& Munuera, 2005). Chen (2009) has developed a theoretical framework which shows that the green brand equity can be enhanced by green brand image, green satisfaction and green trust. He considered the green brand image, green satisfaction and green trust to be the drivers that increase the green brand equity, in an attempt to find a stand point to evaluate concepts of green marketing under the new environmental trends. The study relied on the definitions of brand image suggested by Keller (1993) and Cretu and Brodie (2007) as a set of perceptions and associations in the mind of the consumer that are linked to the market offering.

Regarding the attitudinal effects of green branding, several authors have suggested that the growing environmental consciousness among consumers leads to generalized positive attitudes towards brands that are perceived as environmentally sound (Bech-Larsen, 1996; Eagly \& Kulesa, 1997; Swenson \& Wells, 1997). Kotler (2001) emphasizes the importance of embracing the marketing concept that focuses on the customer. Therefore, green branding enhanced by green quality products can bring green customer satisfaction and green customer loyalty. Customer satisfaction is influenced by attitude. It is therefore expected that two distinct 
processes in the perception of green brand attributes lead to the formation of brand attitudes.

According to the expectancy-disconfirmation paradigm, a comparison of customers' expectations and perceptions would lead to either confirmation or disconfirmation (Oliver, 1993). When the perceptions of customers exactly meet their expectations, their expectations are confirmed (Jiang \& Rosenbloom, 2005). Satisfaction resulting from the performance of the product or brand to fulfill customer needs, desires, and expectations is regarded as the extent of overall delight experienced by a customer (Olsen, 2002). A general consensus has postulated for more than half a century that price is a strong cue for the perceived quality and that price perception affects customer satisfaction (Prakash, 2002; Cretu \& Brodie, 2007). A controversy exists in the other variables of promotion and green distribution where some studies concluded that attitudes towards advertising disclosures impact on perceptions. There is also a negative relationship between green distributions on satisfaction (Poist \& Murphy, 2003). The current author contends that customers have a high level of involvement regarding environmental issues as a consequence of growing environmental consciousness hence a significant influence of environmental knowledge and consciousness on consumer environmental perception.

\subsection{Research Methodology}

The study adopted a descriptive cross-sectional research design to determine how green marketing practices and perception impacted on customer satisfaction in soft drink companies in Nairobi, Kenya. The choice of this design was appropriate for the study since it utilizes a questionnaire as a tool of data collection. This is supported by Gall et al ( 2003) who asserted that this type of design enables one to obtain information with sufficient precision so that hypothesis can be tested properly. The study focused on trade customers of soft drink industries who have a direct link with the supplier/ manufacturers. The study targeted a sample of 180 trade customers but, the researcher managed to successfully collect data from 130 of the trade customers. The researcher considered this population appropriate because soft drink firms ware likely to have adopted green marketing practices owing to customers concerns on health and environment issues.

The relevant data was collected from both secondary and primary sources. Primary data was collected on the study variables through the use of a semi- structured questionnaire. Key informant method was used to administer questionnaires. It is described as obtaining data from persons whose professional and/or organizational responsibilities indicate that they have knowledge about specific characteristics of the population being studied (Warheit, Bulh and Bell, 1978; O'cass et al., 2004). Descriptive statistics (mean scores and measures of dispersion) and inferential statistics (correlation, analysis of variance and regression analysis) was conducted to determine the expected relationships between green marketing practices and Satisfaction. Saunders et. al (2009) emphasized on the importance of descriptive analysis since it forms the basis of correlation and experimental studies. Regression analysis was carried out to measure the relationship between variables and also establish the strength of linear association between the variables. A 95\% confidence level was used in this study. The general formula for predicting customer satisfaction was presented by the model.

\subsection{Findings and Discussions}

The determinants of green marketing practices were assessed by fourteen measures as depicted in Table 1. The results are based on the scale of 1 to 5 (where $5=$ to the greatest extent and 1 is to the lowest extent). According to the respondents competitive forces with a mean score of 3.81 determine green marketing practices adoption to a great extent. This was followed by increasing number of green consumers and their willingness to buy green products (mean score 3.75). However, Competitive advantage (mean score 3.15) and moral and ethical reasons (mean score 3.25) all had relatively lower influence on green marketing practices adoption to a moderate extent. 
Table 1: Determinants of green marketing practices

\begin{tabular}{|c|c|c|c|c|}
\hline \multirow[t]{2}{*}{ Determinants of green marketing practices } & \multicolumn{3}{|c|}{ Mean } & \multirow{2}{*}{$\begin{array}{c}\text { CV } \\
\% \\
\end{array}$} \\
\hline & $\mathbf{N}$ & Score & SD & \\
\hline Compliance with government regulation & 130 & 3.550 & 1.079 & 30.4 \\
\hline Society concerns for the environmental & 130 & 3.400 & 1.010 & 29.7 \\
\hline Increasing number of green consumers \& their willingness to buy green products & 130 & 3.750 & 1.089 & 29.0 \\
\hline Environmental problems that threaten the environment \& human life & 130 & 3.700 & 1.144 & 30.9 \\
\hline Competitive forces & 130 & 3.810 & 1.029 & 27 \\
\hline Profitability goals & 130 & 3.730 & 1.434 & 37.8 \\
\hline Competitive advantage & 130 & 3.150 & 1.013 & 32.1 \\
\hline Moral and ethical reasons & 130 & 3.250 & .993 & 30.6 \\
\hline Top management initiative \& environmental knowledge & 130 & 3.254 & .993 & 30.5 \\
\hline Stakeholders pressure & 130 & 3.253 & .993 & 30.5 \\
\hline Size of the firm of the nature $\&$ industry & 130 & 3.500 & .806 & 23.0 \\
\hline Community\& environmental groups pressure & 130 & 3.550 & .804 & 22.6 \\
\hline Individual employees \& management initiative & 130 & 3.550 & .739 & 20.8 \\
\hline Leadership values \& managerial altitude & 130 & 3.500 & .806 & 23.0 \\
\hline
\end{tabular}

\section{Source: Primary Data}

The results revealed that the determinants of green marketing practices varied from one measure to another. Profitability goal had the highest coefficient of variance $(37.8 \%)$ followed by competitive advantage with $(\mathrm{CV}=$ $32.1 \%)$. The lowest variance was reported in individual employees and management initiatives $(\mathrm{CV}=20.8 \%)$.

The findings particularly on the compliance with government regulations with the highest means score are consistent with the existing literature which classified green marketing activities into the defensive approach and the assertive approach where Companies that adopt defensive green marketing do only the minimum to fulfill local government environmental regulations in order to avoid penalties (McDaniel \& Rylander, 1993). While companies that employ assertive approach are more aggressive in their marketing campaigns. They respond not only to the regulations and the trends of market, but also the requirements of their stakeholders.

Consumer perception emphasizes on the process attribute experiences through psychological development into summary forms such as attitudes that influence customer satisfaction (Schiffman \& Kanuk, 2007). The understanding of customer perception by the firms leads to enhanced customer satisfaction. The trade customers were asked to tick appropriately against three measures as shown in Table 1. Relevant results are presented on the scale of 1 to 5 (where $5=$ to the greatest extent and 1 is to the lowest extent) using meanscores.

Table 2: Trade Customer Perception

\begin{tabular}{|c|c|c|c|c|}
\hline Measures & $\mathbf{N}$ & $\begin{array}{l}\text { Mean } \\
\text { score }\end{array}$ & SD & $\begin{array}{l}\mathrm{CV} \\
\%\end{array}$ \\
\hline $\begin{array}{l}\text { Your desire for soft drink features that } \\
\text { are critical to green product quality }\end{array}$ & $\begin{array}{l}130 \\
130\end{array}$ & $\begin{array}{l}3.70 \\
4.20\end{array}$ & $\begin{array}{l}0.255 \\
0.211\end{array}$ & 6.9 \\
\hline $\begin{array}{l}\text { Your imagery of a soft drink green brand's } \\
\text { features }\end{array}$ & 130 & 2.50 & 0.325 & 5.0 \\
\hline $\begin{array}{l}\text { Your imagery of the soft drink green firms } \\
\text { characteristics } \\
\text { Others Specify }\end{array}$ & 130 & 3.30 & 0.231 & $\begin{array}{l}13.0 \\
7.0\end{array}$ \\
\hline
\end{tabular}

Source: Primary Data

The results in Table 2 revealed that customer's green brand features (Green brand image) was ranked highest (mean scores $=4.20, \mathrm{SD}=0.211, \mathrm{CV}=5 \%$ ). This observation shows the need for marketing managers in the soft drink industry to enhance green brand feature in gaining a competitive edge. This was followed by green perceived quality (mean score $=3.70, \mathrm{SD}=0.255, \mathrm{CV}=6.9 \%$ ) then others (mean score $=3.30, \mathrm{SD}=0.231, \mathrm{CV}=7 \%$ ) and finally green firm characteristics (mean score $=2.5, \mathrm{SD}=0.325, \mathrm{CV}=13 \%$ ). In view of this, green firm imagery was ranked the lowest and with the largest standard deviation signifying varying views about the concept. The findings agree with Kabare (2013) observation that firm imagery had low ratings in terms of how customers recognize the manufacturing firms' characteristics.

Trade customer satisfaction was the dependent variable in the current study and was measured using repeat purchases, complaint handling behavior and the overall customer satisfaction. Rating was on a scale of 1 to 5 
(where for overall satisfaction $5=$ Very satisfied and $1=$ very dissatisfied, repeat purchases $5=$ extremely likely and $1=$ extremely unlikely, complaint handling behavior $5=$ Very satisfied and $1=$ very dissatisfied and for intention to recommend $5=$ extremely likely and $1=$ extremely unlikely). A mean score of 2.5 meant that the trade customer was neither satisfied nor dissatisfied or was undecided to whether or not to repeat buying or recommend the soft drink supplier to friends. The results are presented in Table 3.

Table 3: Trade Customer Satisfaction

\begin{tabular}{|c|c|c|c|c|}
\hline Measures & $\mathbf{N}$ & $\begin{array}{l}\text { Mean } \\
\text { Score }\end{array}$ & SD & $\begin{array}{l}\text { CV } \\
\%\end{array}$ \\
\hline Repeat Purchases & 130 & 4.10 & 0.266 & 6.5 \\
\hline Customer complaint Behaviour & 130 & 2.20 & 0.191 & 8.7 \\
\hline Recommendations & 130 & 3.50 & 0.365 & 10.4 \\
\hline Overall Satisfaction & 130 & 3.90 & 0.282 & 7.2 \\
\hline
\end{tabular}

Source: Primary Data

The results in Table 3 show that Repeat purchases had the highest mean score (4.10) followed by Recommendations with a mean of 5.50. This implies that majority of trade customers would continue purchasing from their current manufacturers to a large extent and they would also recommend others to their supplier or manufacturers to a moderate extent. Overall satisfaction was ranked second with mean score (3.90) and customer complaint behavior had the lowest mean score (2.20). It is therefore necessary for the manufacturers/ supplies to work on the complaint handling aspect. The mean of 2.20 being the lowest implies that the trade customer is not satisfied with the way the suppliers handle their complaints.

To assess the mediating effect of customer perception on the relationship between green marketing practices and customer satisfaction, the latter was regressed on green marketing practices while controlling for the effect of customer perception to determine the value of $\mathrm{R}^{2}$ change and coefficients for green marketing practices. According to Shaver (2005), if $\mathrm{R}^{2}$ is statistically insignificant, it would imply full mediation otherwise it would be partial. The procedure for testing the mediation effect was as presented in Table 4.

Table 4: Regression Results of Green marketing practices and Customer Satisfaction

Model Summary

\begin{tabular}{llllllll}
\hline Model & R & R Square & $\begin{array}{l}\text { Adjusted } \\
\text { Square }\end{array}$ & $\begin{array}{l}\text { Std. Error of } \\
\text { Estimate }\end{array}$ & $\begin{array}{l}\text { the } \\
\text { Change }\end{array}$ & Square \\
\hline 1 & $.389(\mathrm{~d})$ & .223 & .149 & 1.0520 & .223 \\
\hline
\end{tabular}

a predictors: (constant), Green Marketing Practices

b Dependent variable: Customer satisfaction

\begin{tabular}{cllllll} 
ANOVA & \multicolumn{1}{l}{} & & \\
\hline Model & & Sum of Squares & Df & Mean Square & F & Sig. \\
\hline & Regression & 12.074 & 1 & 12.074 & 12.921 & $.002 *$ \\
& Residual & 91.255 & 129 & 1.314 & & \\
& Total & 103.329 & 130 & & & \\
\hline
\end{tabular}

a predictors: (constant), Green marketing practices

b dependent variable: Customer satisfaction

\section{Coefficients}

\begin{tabular}{|c|c|c|c|c|c|c|c|}
\hline Model & & & $\begin{array}{l}\text { Unsta } \\
\text { Coeff }\end{array}$ & lized & $\begin{array}{l}\text { Standardized } \\
\text { Coefficients }\end{array}$ & & \\
\hline \multirow{3}{*}{1} & & & B & Std. Error & Beta & $\mathrm{T}$ & Sig. \\
\hline & (Constant) & & 4.906 & 5.993 & & 5.155 & .004 \\
\hline & $\begin{array}{l}\text { Green } \\
\text { practices }\end{array}$ & marketing & .209 & 1.637 & .389 & 2.571 & .002 \\
\hline
\end{tabular}

a Dependent Variable: Customer satisfaction; Level of significance, $\alpha=0.05$

Source: Primary Data

The results in Table 4 show that green marketing practices explains $22.3 \%$ of the variation in customer satisfaction $\left(\mathrm{R}^{2}=.223\right)$. The results indicate that the overall model is statistically significant at $\alpha=.05$. The first step implies that the relationship between green marketing practices and customer satisfaction is positive and statistically significant.

In the second step, a regression analysis to assess the relationship between green marketing practices and customer perception was conducted. In this step, green marketing practices was treated as the independent variable and customer perception as the dependent variable. The results are summarized in Table 5. 
Table 5: Regression Results of Green Marketing Practices and Customer Perception The Goodness-of-Fit

\begin{tabular}{llllllll} 
Model & R & R Square & $\begin{array}{l}\text { Adjusted } \\
\text { Square }\end{array}$ & R $\begin{array}{l}\text { Std. Error of } \\
\text { Estimate }\end{array}$ & $\begin{array}{l}\text { the } \\
\text { Rhange }\end{array}$ \\
\hline 1 & $.349(\mathrm{~d})$ & .121 & .102 & 1.0327 & .121 \\
\hline
\end{tabular}

a Predictors: (Constant), Green marketing practices

ANOVA

\begin{tabular}{lllclll}
\hline Model & & Sum of Squares & Df & Mean Square & F & Sig. \\
\hline 1 & Regression & 11.982 & 5 & 2.396 & 5.240 & $.052(\mathrm{e})$ \\
& Residual & 91.347 & 125 & 1.213 & & \\
& Total & 103.329 & 130 & & & \\
\hline
\end{tabular}

a Predictors: (Constant), Green marketing practices

b. Dependent Variable: Customer perception

Coefficients(a)

\begin{tabular}{|c|c|c|c|c|c|c|}
\hline & & Unstanda & Coefficients & $\begin{array}{c}\text { Standardized } \\
\text { Coefficients }\end{array}$ & & \\
\hline \multirow{2}{*}{$\begin{array}{l}\text { (Constant) } \\
\text { Green } \\
\text { practices }\end{array}$} & \multirow[b]{2}{*}{ marketing } & $\begin{array}{c}\mathrm{B} \\
2.624\end{array}$ & $\begin{array}{c}\text { Std. Error } \\
.493\end{array}$ & Beta & $\begin{array}{c}\mathrm{T} \\
3.456\end{array}$ & $\begin{array}{l}\text { Sig. } \\
.004\end{array}$ \\
\hline & & .298 & .325 & .226 & 2.342 & .002 \\
\hline
\end{tabular}

a Dependent Variable: Customer perception

The results in Table 5 portray that green marketing practices explains 12.1 percent of the variation in customer perception $\left(\mathrm{R}^{2}=.121\right)$. The results of the overall model reveals that the relationship between green marketing practices and customer perception is positive though not statistically significant at $\alpha=.05(\mathrm{~F}=5.240, \mathrm{p}$ value=.052). This means that green marketing practices may not predict customer perception outcome of the firms. The beta coefficients also indicate that statistically significant linear relationship between customer perception and green marketing practices was detected $(\beta=.349, \mathrm{p}=.002)$.

Finally, a regression analysis was performed and the betas examined for the strength, direction and significance of the relationship. In step one, customer satisfaction was regressed on the green marketing while in step two customer perceptions was regressed on green marketing practices to assess if there was a significant change. When controlling for the effects of the customer perception on satisfaction, the effect of the green marketing practices on the customer satisfaction should no longer be statistically significant at $\alpha=.05$. The relevant results are summarized in Table 6. 
Table 6: Regression Results of customer perception on customer satisfaction and green marketing Model Summary

\begin{tabular}{ccccccccc}
\hline R & $\begin{array}{c}\text { R } \\
\text { Square }\end{array}$ & $\begin{array}{c}\text { Adjusted R } \\
\text { Square }\end{array}$ & $\begin{array}{c}\text { Std. Error of the } \\
\text { Estimate }\end{array}$ & \multicolumn{3}{c}{ Change Statistics } \\
\hline & & & & R Square & F & & Sig. F \\
& & & & Change & Change & df1 & df2 & Change \\
.385 & .148 & .0787 & 1.248 & .148 & 10.018 & 2 & .130 & .006 \\
.394 & .153 & .0566 & 1.036 & .0566 & 7.118 & 1 & .129 & .0142 \\
\hline
\end{tabular}

a Predictors: (Constant), Customer Perception, b Predictors: (Constant), Customer Perception, Green Marketing ANOVA

\begin{tabular}{lllllll}
\hline Model & & Sum of Squares & DF & Mean Square & F & Sig. \\
\hline 1 & Regression & 98.318 & 1 & 13.218 & 10.018 & 0.006 \\
& Residual & 90.640 & 129 & 1.124 & & \\
\multirow{2}{*}{2} & Total & 188.958 & 130 & & 7.118 & 0.002 \\
& Regression & 97.018 & 2 & 10.218 & & \\
& Residual & 91.640 & 128 & 1.124 & & \\
& Total & 188.658 & 130 & & & \\
\hline
\end{tabular}

a Predictors: (Constant), Customer Perception,

b Predictors: (Constant), Customer Perception, Green Marketing,

c Dependent Variable: Customer Satisfaction

\section{Coefficients}

\begin{tabular}{clccccc}
\hline $\begin{array}{c}\text { Mode } \\
1\end{array}$ & & \multicolumn{2}{c}{$\begin{array}{c}\text { Unstandardized Coefficients } \\
\text { B }\end{array}$} & \multicolumn{1}{c}{$\begin{array}{c}\text { Standardized Coefficients } \\
\text { Beta }(\boldsymbol{\beta})\end{array}$} & \multicolumn{2}{c}{$\begin{array}{c}\text { Sign. } \\
\text { Level }\end{array}$} \\
\cline { 2 - 7 } & & 1.446 & .482 & & 1.402 & 1.038 \\
& (Constant) & .402 & 486 & 1.068 & .004 \\
2 & Customer Perception & .451 & .382 & & 1.231 & .038 \\
(Constant) & 1.446 & .302 & .492 & 1.868 & .004 \\
& Customer Perception & .451 & .112 & .332 & .765 & 0.00 \\
\hline
\end{tabular}

Predictors: Customer perception, green marketing practices

Dependent Variable: Customer Satisfaction

Source: Primary Data

The results in Table 6 reveal change in $R^{2}$ change $\left(R^{2}=0.0566\right)$ and that of beta coefficient $(\beta=0.732)$. At step 2, customer perception, adds significantly to the customer satisfaction as the variation increased from .385 to $.394(\mathrm{R} 2$ change $=.019 \mathrm{p}$-value $=.002)$. The results reveal that the variance explained by customer perception is significant $(\mathrm{F}=10.018$, $\mathrm{p}$-value=.006). The results also revealed that the regression coefficients for green marketing practices reduced from .389 to .332 when customer perception were added to the regression suggesting that customer perception may be exerting a partial mediating effect. Both statistics were statistically significant $(p<0.05)$ indicating partial mediation. This implies that changes in the customer perception may positively affect green marketing practices and customer satisfaction relationship as the direction of the relationship is positive.

Table 7 presents a summary of the mediated regression analysis. 
Table 7: Summary of Mediating Effect of Customer Perception on the Relationship between green marketing practices and customer satisfaction

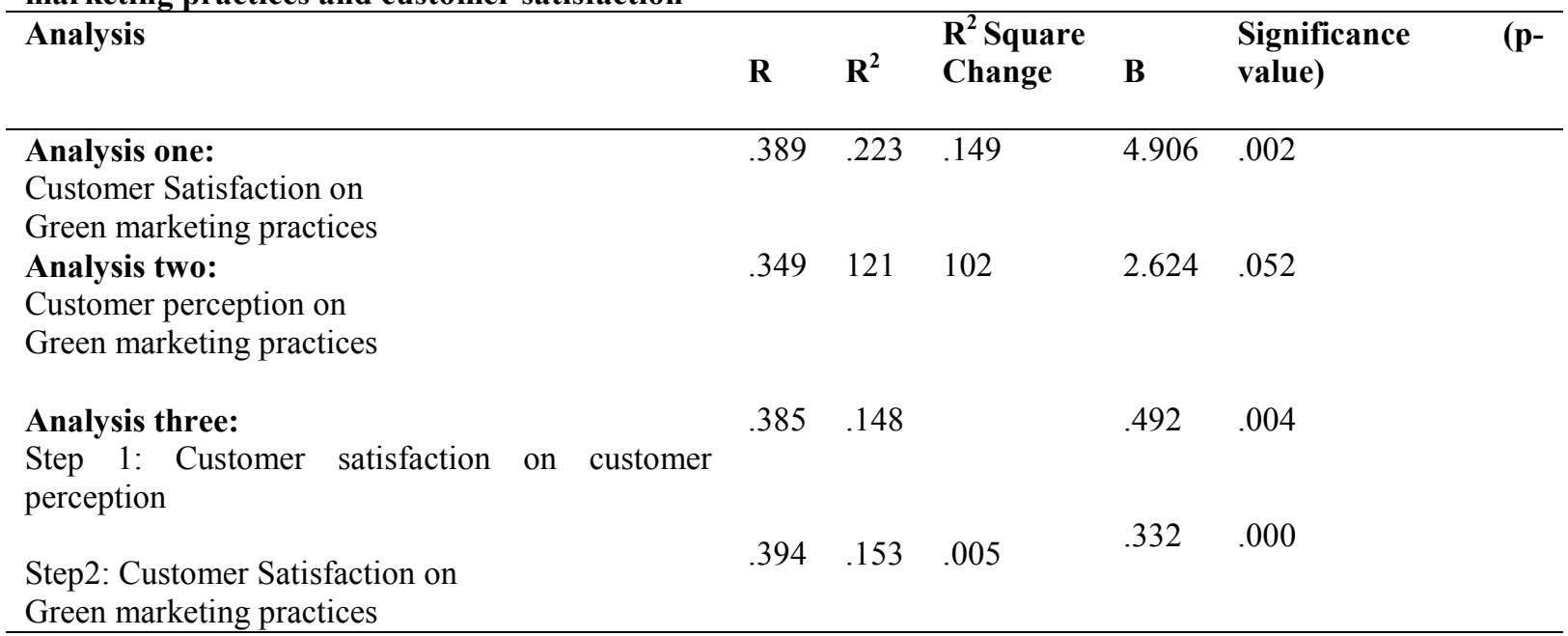

Figure 1: Modified Mediating Effect of Customer perception on the Relationship between Green marketing practices and customer satisfaction

Part A: Overall Direct Effect

Path c

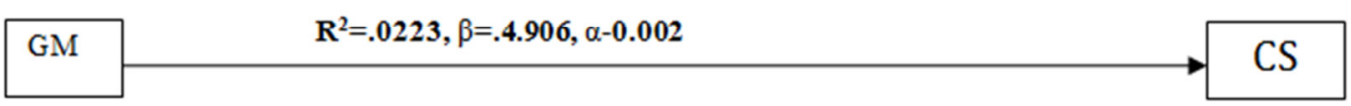

Source: Primary Data.

Part B: Path Diagram for Mediation Effect of Customer perception

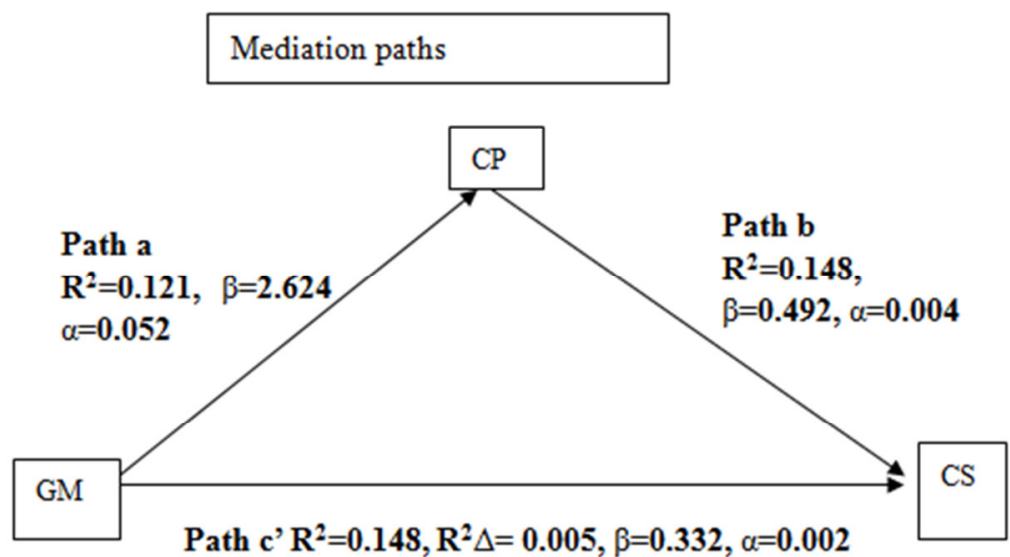

$\mathrm{GM}=$ Green marketing practices; $\mathrm{CP}=$ Customer perception; $\mathrm{CS}=$ Customer satisfaction

\section{Conclusions, Recommendations and Limitations}

\subsection{Conclusions,}

The results of the study revealed that the relationship between green marketing practices and customer satisfaction in the soft drink industry in Nairobi Kenya was statistically positive and also highly significant $(\mathrm{p}<$ $0.05)$. The pertinent results show that $\mathrm{R}^{2}$ increased from .121 to .223 when customer perceptions were included $(.223-.121=.102)$. The results imply that customer perception explain an additional $10.2 \%$ of the variation in customer satisfaction. The results indicate that the effect of green marketing practices on customer satisfaction in the final step of the analysis (path c) is significant at 0.05 significance level. The regression coefficient reduced from $\beta=.389$ in path "a" to $\beta=.349$ in path c' and was statistically significant at 0.05 level of significance. This indicated partial mediation. This explains part of the effect of the green marketing practices as mediated by the customer perception but other parts are either direct or mediated by other variables not in the study. 
This explains part of the effect of the green marketing practices as mediated by the customer perception but other parts are either direct or mediated by other variables not in the study.

\subsection{Implications of the Study}

The current research examined the correlation among green marketing practices, perception of customers and the satisfaction of customers. Customer perception mediating roles were well explored. The study results present theoretical, Practical and policy implications. The study has added value to customer satisfaction theory by adding an enabler variables namely; customer perception as a mediator variables. Customer perception had a positive and significant mediation effect on the correlation between Customer Satisfaction and green marketing practices. The implication of the results to the practice is that green marketing is a worthwhile strategy which the management should be committed to in order to gain competitive advantage in a competitive industry with changing dynamic marketing environment. The findings will therefore assist the marketing managers to convince the senior management and business owners on green marketing issues to be implemented due to widespread perception that green promotion may have a negative impact on sales due to "green wash"(Polonsky, 2001). Further, managers will realize that green marketing practices serve the purpose of dealing with the organization's direct or indirect actual or potential negative impact to the environment in satisfying consumer needs.

The findings will also help managers understand that businesses in all industries get affected by environmental concerns and therefore firms' should be sensitive to these influences so as to remain competitive globally. Finally, marketers should inform, persuade and remind consumers on the benefits of green products through green promotion because the general population in developing countries such as Kenya has low knowledge about environmental concerns and their implication to individuals and the economy as whole. This is likely to increase the understanding of consumers as well as improve customer perceptions about green products.

The results of this study also have major policy implications on the government. Green marketing approach could be used to help the country address environmental problems. Mainstreaming green marketing in private and public firms operations has potential to add value in the pursuit of sustainable development in the area of clean and sustainable environment, a goal that is also captured within the social pillar of Kenyas Vision 2030 (Government of Kenya 2007). The government should encourage both local and multinational companies to implement green marketing practices effectively and efficiently.

\subsection{Limitations of the Study and suggestions for further research}

Like others, this study has limitations that constrain the generalization of the study. A study based on a single sub-sector in the food \& Beverage sector limits the generalizability of the results across all sectors. Although industry specific research enhances internal validity, special attention should be taken when generalizing to other sectors. It should be kept in mind that findings in soft drink companies sub sector context may not necessarily translate into another sector context like telecommunication sector. Other limitations related to limited resources available at the time the research was conducted. The constraints influenced the scope of the study but this did not affect the conduct of the research due to appropriate design arrived at.

\section{REFERENCES}

Aaker, D., \& Shansby, J. (1982). Positioning your product. Business Horizons, 25(5), 56-62.

Banerjee, S. B. (1999). Corporate Environmentalism and greening of strategic marketing, Implications for marketing theory and practice: Greener marketing, a global marketing. Perspective on greening marketing practice edited by charter M and Polonsky M.J ( $2^{\text {nd }}$ ed $)$. Sheffield UK: Greenleaf publishing.

Baron, R.M., \& Kenny, D.A. (1986), The moderator-mediator variable distinction in social psychological research: Conceptual, strategic and statistical considerations. Journal of Personality and Social Psychology, $51,1173-82$.

Bartels, R. (1968). The General theory of marketing. Journal of Marketing. (32)(1), 29-33.

Buil-carrasco, I., Fra-Andres, E., \& Matute,V. J. (2006), Corporate environmentalism strategy in the Spanish consumer product sector: A Typology of firms, business strategy and environment. Published online at www. interscience.wiley.com .1-21.

Carmona, S. E., Cespedes, J., \& Burgos-Jimenez, J. (2004). Environmental Strategies in Spanish Hotels: Contextual Factors and Performance. Service Industries Journal 24(3), 101-130.

Chamorro, A., \& Banegil, T.M. (2006). Green marketing philosophy: A study of Spanish firms with Eco-labels. Corporate social responsibility and Environmental management, 24, 11-24.

Chen, Y. S. (2010). The drivers of green brand equity: green brand image, green satisfaction, and green trust. Journal of Business Ethics, 93(2) 307-327.

Cunningham, L.F., Gerlach, J. \& Harper, M.D. (2004). Assessing perceived risk of consumers in internet airline reservations services. Journal of Air Transportation, 9(1) 21-35. 
Fairchild, A. J., \& MacKinnon D. P. (2009). A General Model for Testing Mediation and Moderation Effects. Prevention Science, 10, 87-99. Press, New Haven, CT, London.

French P.D., Sutton S., Hennings J.S., Mitchell J., Wareham J.N., Hardeman W., Griffin S., and Kinmonth L.A. (2005). The Importance of affective beliefs and attitudes in the theory of Planned Behaviour: Predicting intention to increase physical activity. Journal of Applied Social Psychology, 35, (9), 1824-1848.

Kabare, N. (2013). Quality Drivers, Managerial focus, Customer perception and Customer satisfaction in large flour mills in Nairobi. Unpublished Ph.D Thesis, University of Nairobi.

Kalafatis, S. P., Tsogas, M. H., \& Blankson, C. (2000). Positioning strategies in business markets. Journal of Business \& Industrial Marketing, 15(6), 416-37.

Klein, A.S., Masi, R.J., \& Weidner, C.K. (1995). Organization Culture, Distribution and Amount of Control, and Perceptions of Quality: An Empirical Study of Linkages, Group \& Organization Management, 20 (2), 122 148.

Kinnear, T. C., \& Taylor, J.R. (1973). The Effect of Ecological Concern on Brand Perceptions. Journal of Marketing Research, 10 (5), 191-197.

Kinoti, M. W. (2012). Green Marketing Practices, Corporate Image, Organization Characteristics And Performance of ISO 9000 \& 14000 Certified Organizations in Kenya. Unpublished Ph.D Thesis University of Nairobi.

Luo, X., \& Bhattacharya, C. B. (2006). Corporate social responsibility, customer satisfaction, and market value. Journal of Marketing, 70, 1-18.

MacKinnon D.P., and Fairchild A.J. (2009). Current Directions in Mediation Analysis. Journal of the Association for Psychological Science, 18 (1), 16-20.

Menon, A., Menon, A., Chowdhury, J., \& Jankovich, J. (1999). Evolving Paradigm for Environmental Sensitivity in Marketing Programs: A Synthesis of Theory and Practice. Journal of Marketing Theory and Practice, 7(2), 1-15.

Mourad, M., \& Ahmed, Y.S.(2012). Perception of Green brand in an emerging innovative market: factors affecting the green brand preference in the telecom industry in Egypt. www.emeraldinsight.com/14601060.htm accessed 15th Sep 2014.

Oliver, R.L. (1997). Satisfaction: A behavioral perspective on the consumer. New York: McGraw-H.

Oliver, R.L. (2006). Customer satisfaction research. The handbook of marketing research. USA:Sage

Ottman, A. J. (2011). Green Marketing trends focusing upon environmental protection. http://www.greenmarketing.com/blogs/category/green trends accessed $20^{\text {th }}$ August 2013.

O'Sullivan, et al. (2009), Marketing performance measures and firm performance: Evidence from the European high-technology sector. European Journal of Marketing, 43(5/6), 843-862.

Min, H \& Galle W. P. (2001), "Green purchasing practices of US firms". International Journal of Operations $\&$ Production Management vol 21 No 9 pp 1222-1238.

Parker, B., Segev, S. \& Pinto, J. (2009). What it means to Go Green: Consumer Perception of Green Brands and Dimensions of Greenness, Florida International University, North Miami, FL.

Paulssen, M. \& Birk, M.M. (2007). Satisfaction and repurchase behavior in a business to-business setting: investigating the moderating effect of manufacturer company and demographic characteristics. Industrial Marketing Management, Vol. 36 No. 7, pp. 983-97.

Polonsky, M. J. (1995). A Stakeholder Theory Approach to Designing Environmental Marketing Strategy.The Journal of Business and Industrial Marketing, 10(3), 29-47.

Rios, F., Martinez, T., Moreno, F. \& Soriano, P. (2006). Improving attitudes toward brands with environmental associations: an experimental approach. The Journal of Consumer Marketing, 23 (1), 26-34.

Schiffman, G. L., \& Kanuk, L. (2009). Consumer Behavior ( $9^{\text {th }}$ Ed). Pearson Prentice Hall.

Shafeiha, S. \& Saeednia, H. (2010). Impact of Customers' Perceptions from Service Brand on Customer ValueLoyalty Process (Iran Insurance Company). International business and Economics research journal, 1(3):232-40.

Sihem, D., \& Mohamed. (2013). Price Fairness in the Case of Green Products: Enterprises' Policies and Consumers' Perceptions studied in Switzerland. Published online 10 December 2013 in Wiley Online Library (wileyonlinelibrary.com) DOI: 10.1002/bse.1763

Song,T. H. (2011). The Role of Firms in China's Green Marketing, University of Ballarat, Australia.

TCCC, (2007). The Coca cola company corporate responsibility. http://www.thecolacolacompany.com/citizenship/economic impact accessed 15th Sep 2014.

Walley, N. \& Whitehead, B. (1994). It's not easy being green. Harvard Business Review, 72( 3) 2-7

Wiener, J. L. \& Doescher, T.A., (1991). A Framework for Promoting Cooperation. Journal of Marketing 55 (April), 38-47.

WPP (2010), "Survey identifies varied green beliefs and behaviors among global consumers", available at: www. wpp.com/wpp/press/press/default.htm?guide accessed 16th July 2014. 